\title{
Biochemical Profile and Assessment of risk factors for Patients Diagnosed with Myocardial Infarction in Al- Ramadi City, Iraq.
}

\author{
Marwan Mahmood Saleh \\ Department of Biophysics, \\ College of Applied Sciences, \\ University of Anbar, Ramadi, Iraq \\ ah.marwan_bio@uoanbar.edu.iq, \\ bio_marwan@yahoo.com
}

\begin{abstract}
Myocardial infarction (MI) continues to be a major cause of mortality and also death at early ages all over the world. This study is undertaken to evaluate the effect of MI on the levels of lipid profile, two enzymatic markers, fasting blood sugar (FBS), urea, creatinine and total serum bilirubin (TSB), rather than to assess the risk factors which lead to $M I$ and its relation to these variables. The sample of the study consisted of (50) patients admitted to the Cardiac Care Unit in Al-Ramadi General hospital. MI patients had significantly $(P \leq 0.05)$ higher levels of triglyceride (TG) $(201.4 \mathrm{mg} / \mathrm{dl})$ as compared with the controls $(142.8 \mathrm{mg} / \mathrm{dl})$, while high density lipoprotein (HDL) significantly $(P \leq 0.05)$ decreased in patients $(42.24$ $\mathrm{mg} / \mathrm{dl}$ ) compared with control group $(58.7 \mathrm{mg} / \mathrm{dl})$. Total cholesterol (TC) (183.6 mg/dl) and low density lipoprotein (LDL) $(109.3 \mathrm{mg} / \mathrm{dl})$ were not affected significantly $(P \leq 0.05)$ in MI group when compared with control group with the average of $(172.2 \mathrm{mg} / \mathrm{dl})$, $(116 \mathrm{mg} / \mathrm{dl})$ respectively. Aspartate aminotransferase (AST) increased significantly $(P \leq 0.05)$ in patients (61.38 IU/L) compared to the control group (23.5 IU/L) , while there was no significant $(P \leq 0.05)$ difference in alkaline phosphatase (ALP) between MI and control group. Levels of fasting blood sugar (FBS) in the serum of MI group $(206 \mathrm{mg} / \mathrm{dl})$ increased significantly $(P \leq 0.05)$ comparing with the control group (122.1 $\mathrm{mg} / \mathrm{dl})$. This study showed increase in urea $(55.6 \mathrm{mg} / \mathrm{dl})$ and creatinine $(1.26 \mathrm{mg} / \mathrm{dl})$ levels in the MI group contrast with the control group which its mean was $(29.8 \mathrm{mg} / \mathrm{dl}),(0.85 \mathrm{mg} / \mathrm{dl})$ respectively. There was no difference in the level of TSB. Findings of this study, stating differences in levels of some biochemical parameters can use as a biomarker of myocardial infarction. There is an increase in the incidence of myocardial infarction and some differences in the level of parameters in the presence of one or more major risk factors.
\end{abstract}

Keywords: Biochemical profile, Myocardial Infarction, risk factors, Al-Ramadi

\section{INTRODUCTION}

MI is the condition when there is evidence in a clinical setting of myocardial necrosis consistent with myocardial ischemia. By pathology, MI is myocardial cell death caused by prolonged ischemia[1]. Acute MI is an event of myocardial necrosis caused by an unstable ischemic syndrome [2]. In practice, the disorder is diagnosed and assessed on the basis of the electrocardiogram (ECG), clinical evaluation, biochemical testing, invasive and noninvasive imaging, and pathological evaluation [3].

Necrosis of the myocardium caused by an obstruction of the blood supply to the heart (coronary circulation) [4]. The most common cause of MI is rupture of an atherosclerotic plaque with the formation of a thrombus leading to occlusion of a coronary artery [5]. The rupture of a plaque results in exposure of collagen, lipids, smooth muscle cells, and tissue factor to the blood, leading to activation of platelets and the coagulation system $[6,7]$.

There are some risk factors that increase the chance of developing MI. They are classify as major and contributing risk factor. Risk factors may also classified into two groups, 1) non-modifiable factors (male gender, increase age, heredity) and 2) modifiable factors (tobacco smoke, diabetes mellitus, high blood cholesterol, high blood pressure, physical inactivity, obesity and overweight). On the other hand, alcohol drinking, stress and an unhealthy diet and nutrition are considered as contributing risk for MI [8].

There are four elements of lipid including total cholesterol (TC), low-density lipoprotein cholesterol (LDL-C), high-density lipoprotein cholesterol (HDL-C), and triglyceride (TG) that are considered as primary influencing factors for developing heart disease. [8] provided the desirable level of cholesterol. TC level should be less than $200 \mathrm{mg} / \mathrm{dl}$, the LDL-C less than 100 $\mathrm{mg} / \mathrm{dl}$, the HDL-C not less than $40 \mathrm{mg} / \mathrm{dl}$ for men and 50 $\mathrm{mg} / \mathrm{dl}$ for women and ideally $60 \mathrm{mg} / \mathrm{dl}$ or higher, the triglyceride less than $150 \mathrm{mg} / \mathrm{dl}$.

[9] explained that diagnosis of MI is based on clinical symptoms, electrocardiographic (ECG) changes and characteristic pattern of changes in some serum enzymes such as AST.

The main aim of the present study was to examine the changes in biochemical profile in MI patients. To analyze the association of age, sex, smoking in addition to past history of angina pectoris, diabetes mellitus (DM) and hypertension.

\section{METHODS AND MATERIALS}

Fifty patients with MI were studied admitted to the cardiac care unit (CCU) and ten people (five male with five female) as control in Al-Ramadi General hospital. They were screened for the presence of one or more major risk factors (Angina pectoris, hypertension, DM, and smoking). 
Blood was drawn for determination of TG, TC, LDL, HDL, AST, ALP, FBS, Urea, Creatinine and TSB. Blood samples from patients and healthy control were transported to the main laboratory in hospital on the same day and transmitted into centrifuge tubes without ethylene diamine tetraacetic acid (EDTA), kept at room temperature for (20-30) minute, centrifuge for (15) minute at (3000) rpm for 15 minutes [10]. Samples were analyzed immediately by Cobas c 311- Roche Diagnostics.

\subsection{Statistical analysis}

Results are shown as numbers and percentages (\%). The statistical analysis was done with Microsoft Excel 2010. The results were evaluated by using $\mathrm{F}$ test to determine the significance of biochemical parameters among two groups. Statistical significance was considered at $\mathrm{P} \leq$ 0.05 .

\section{RESULTS}

TG, AST, FBS, urea and creatinine were increased in patients as compared with the controls. HDL decreased in patients as compared with the controls. The study showed no significant differences in levels of TC, LDL, ALP and TSB in patients and controls (Figure 1-5).

The study showed that $64 \%$ of patients were male and $36 \%$ of patients were female, levels of parameters showed no significant $(\mathrm{P} \leq 0.05)$ differences according to sex in the studied group (Table 1).

There was no statistical difference with parameters between all ages groups (Table 2).

In current study $54 \%$ of the patients were smokers and there was an increase in lipid profile but was not significant $(\mathrm{p} \leq 0.05)$ (Table 3$)$.

The past history of angina pectoris have increased all parameters studied statistically significant $(\mathrm{p} \leq 0.05)$ (Table 4).

The past history of DM and hypertension were, more common in the cases, increased FBS statistically significant $(\mathrm{p} \leq 0.05)$ (Table 5).

\section{DISCUSSION}

MI is a life threatening disease and MI occurs when a complete cutoff of the blood supplies result in the death of heart cells. Eighty to ninety percent of all acute MI can develop a secondary thrombus [11]. When a thrombus, perfusion to the myocardial distal to the occlusion is halted, resulting in necrosis [11]. Once MI develops, without prompt treatment, it can damage the affected part of the heart.

According to the present study, result was in agreement findings of [12], [13], [14] studies that showed that serum triglyceride, total cholesterol, LDL-C increased and decreased HDL-C in MI patients as compared with the controls. There is a different mechanism about an elevation of triglycerides after MI. It is reported that elevated triglyceride levels may depend on the genetic basis [15] and nutritional habits [16]. Several studies have supported that the ratios of LDL-C/HDL-C and total cholesterol/HDL-C show the atherosclerotic injury of the wall of the vessels [17], [18].

Our results were in agreement with [19] who showed there was a significant increase in AST activity in MI group. In MI patients myocardium death and necrosis therefore enzymes release in great concentration to blood and increasing its activity [20].

In current study, 54\% of patients were smoking. Smoking is significant risk factor for MI and death. The incidence of smoking caused $71 \%$ of $\mathrm{MI}$ and $37 \%$ of death [21]. The risk is higher by three to four times than that of the non-smoker. The adverse effect of cigarette smoke includes increased catecholamine, increased myocardial oxygen demand, increased blood pressure and heart rate, impaired oxygen exchange, and increased carboxyhemoglobin that can produce or exacerbate myocardial ischemia [22].

The current study showed variations in parameters in patients with MI past history of angina pectoris. Several mechanisms accounting for these changes include the acute phase response [23], [24] associated with upregulation of (LDL) receptor activity [25] and reduction in several pivotal (HDL) regulatory proteins [26]. In addition, stress-induced myocardial injury and necrosis facilitates adrenergic mediated adipocyte lipolysis leading to free fatty acid mobilization, enhanced hepatic very-low-density lipoprotein (VLDL) secretion, TG elevation, and alteration in LDL and HDL particle composition [27].

In this study, $66 \%$ of patients have diabetes and hypertension (18\% DM, 18\% hypertension and 30\% DM with hypertension). Higher incidence of diabetes, hypertension, hyperlipidemia, family history, smoking, obesity and inactivity have been proposed as possible contributing factors [28]. [29] found that diabetes is common in patients with MI as pair disease prevalence. In patients with MI it is the largest cause of excess mortality among diabetic patients. Diabetes acts as an associated disease with an increased risk of myocardial infarction. MI is two to three times more common among diabetic people and carries a worse prognosis than in the general population [30]. Hyperglycemia of diabetes fosters dyslipidemia, increase platelet, and alters red blood cell function which can lead to thrombus formation [31].

\subsection{Figures and Tables}

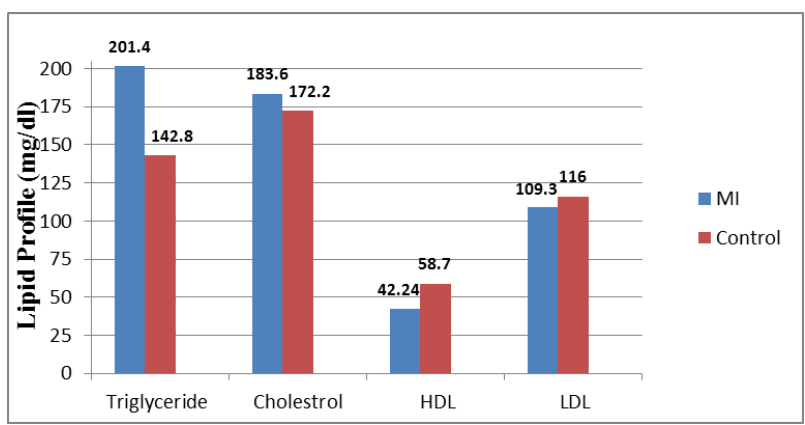

Figure 1 lipid profile in MI patients and control groups. 


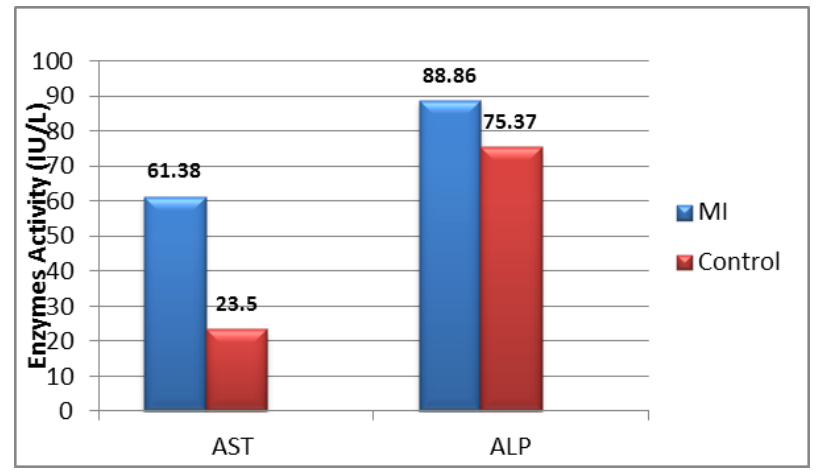

Figure 2 Enzymes activity in MI patients and control groups.

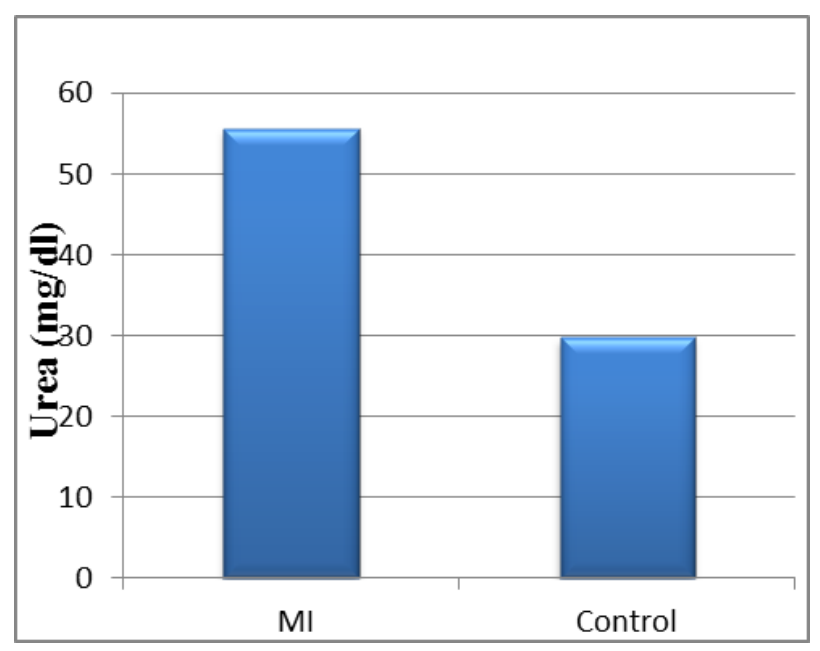

Figure 3 Urea concentration in MI patients and control.

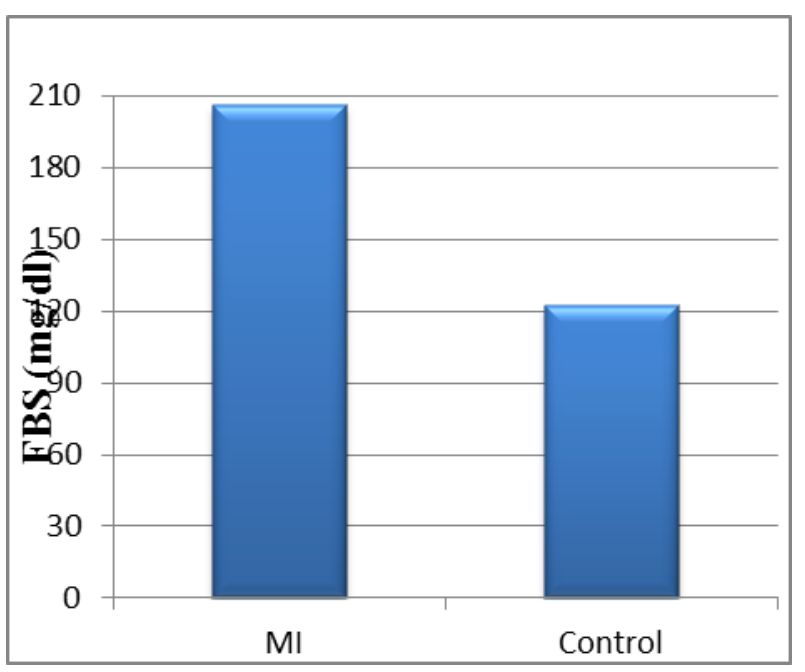

Figure 4 FBS concentration in MI patients and control.

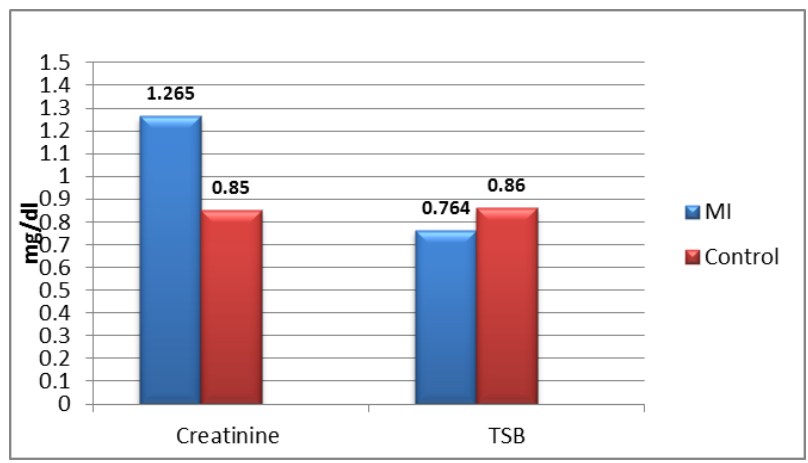

Figure 5 Creatinine and TSB concentration in MI patients and control.

\subsection{Tables}

Table 1: The prevalence of MI according to sex and relation with parameters.

\begin{tabular}{|c|c|c|c|c|}
\hline Gender & Male & Female & $\begin{array}{c}\text { MI General } \\
\text { Mean }\end{array}$ & $\begin{array}{c}\text { Control } \\
\text { Mean }\end{array}$ \\
\hline No.(\%) & $32(64)$ & $18(36)$ & 50 & 10 \\
\hline TG & 225.9 & 158 & 201.4 & 142.8 \\
\hline TC & 184.6 & 181.7 & 183.6 & 172.2 \\
\hline LDL & 109.41 & 109.13 & 109.31 & 116 \\
\hline HDL & 40.84 & 44.72 & 42.24 & 58.7 \\
\hline AST & 60.97 & 62.11 & 61.38 & 23.5 \\
\hline ALP & 85.81 & 92.56 & 88.86 & 75.37 \\
\hline FBS & 188.9 & 236.7 & 206.1 & 122.1 \\
\hline Urea & 57.81 & 64.89 & 55.64 & 29.8 \\
\hline Creatinine & 1.679 & 1.583 & 1.265 & 0.85 \\
\hline TSB & 0.777 & 0.751 & 0.764 & 0.86 \\
\hline
\end{tabular}

No significant $(\mathrm{p} \leq 0.05)$ changes observed in all parameters in both sexes as compared to MI general mean.

Table 2: The prevalence of MI according to age groups and relationship with biochemical parameters.

\begin{tabular}{|c|c|c|c|c|c|c|}
\hline $\begin{array}{c}\text { Age } \\
\text { (year) }\end{array}$ & $38-48$ & $49-59$ & $60-70$ & $>70$ & $\begin{array}{c}\text { MI } \\
\text { General } \\
\text { Mean }\end{array}$ & $\begin{array}{c}\text { Control } \\
\text { Mean }\end{array}$ \\
\hline No.(\%) & $\begin{array}{c}13 \\
(26)\end{array}$ & $\begin{array}{c}12 \\
(24)\end{array}$ & $\begin{array}{c}12 \\
(24)\end{array}$ & $\begin{array}{c}13 \\
(26)\end{array}$ & 50 & 10 \\
\hline TG & 201.1 & 196.3 & 196.2 & 202.7 & 201.4 & 142.8 \\
\hline TC & 183.3 & 176.9 & 181 & 184.7 & 183.6 & 172.2 \\
\hline LDL & 105.33 & 93.73 & 104.02 & 107.4 & 109.31 & 116 \\
\hline HDL & 41.73 & 43.91 & 37.75 & 42.03 & 42.24 & 58.7 \\
\hline AST & 63.98 & 60.75 & 74 & 62.85 & 61.38 & 23.5 \\
\hline ALP & 91.38 & 91.33 & 85.75 & 90 & 88.86 & 75.37 \\
\hline FBS & 203.3 & 194.8 & 176.8 & 209.2 & 206.1 & 122.1 \\
\hline Urea & 61.02 & 51.08 & 74.58 & 60.41 & 55.64 & 29.8 \\
\hline Creatinine & 1.539 & 1.228 & 2.604 & 1.413 & 1.265 & 0.85 \\
\hline TSB & 0.785 & 0.925 & 0.692 & 0.778 & 0.764 & 0.86 \\
\hline
\end{tabular}

No significant $(\mathrm{p} \leq 0.05)$ changes observed in all parameters in age groups as compared to MI general mean. 
Table 3: The relationship between the smoking and levels of parameters in MI patients.

\begin{tabular}{|c|c|c|c|c|}
\hline Factor & $\begin{array}{c}\text { (MI)Cigarett } \\
\text { e smokers }\end{array}$ & $\begin{array}{c}\text { (MI) } \\
\text { Non } \\
\text { Smoker }\end{array}$ & $\begin{array}{c}\text { MI } \\
\text { General } \\
\text { Mean }\end{array}$ & $\begin{array}{c}\text { Control } \\
\text { Mean }\end{array}$ \\
\hline No.(\%) & $27(54)$ & $23(46)$ & 50 & 10 \\
\hline TG & 177.8 & 229.2 & 201.4 & 142.8 \\
\hline TC & 184.9 & 182.1 & 183.6 & 172.2 \\
\hline LDL & 118.06 & 99.035 & 109.31 & 116 \\
\hline HDL & 44.185 & 39.957 & 42.24 & 58.7 \\
\hline AST & 63.48 & 58.91 & 61.38 & 23.5 \\
\hline ALP & 86.44 & 91.7 & 88.86 & 75.37 \\
\hline FBS & 208.4 & 203.3 & 206.1 & 122.1 \\
\hline Urea & 56.78 & 54.3 & 55.64 & 29.8 \\
\hline Creatinine & 1.145 & 1.407 & 1.265 & 0.85 \\
\hline TSB & 0.778 & 0.748 & 0.764 & 0.86 \\
\hline
\end{tabular}

No significant $(\mathrm{p} \leq 0.05)$ changes observed in all parameters in two groups as compared to MI general mean.

Table 4: The relationship between past history of angina pectoris and levels of parameters in MI patients.

\begin{tabular}{|c|c|c|c|c|}
\hline Health state & $\begin{array}{c}\text { (MI) } \\
\text { with } \\
\text { Angina } \\
\text { pectoris }\end{array}$ & MI only & $\begin{array}{c}\text { MI } \\
\text { Genera } \\
1 \text { Mean }\end{array}$ & $\begin{array}{c}\text { Control } \\
\text { Mean }\end{array}$ \\
\hline No.(\%) & $20(40)$ & $30(60)$ & 50 & 10 \\
\hline TG & $202.2^{*}$ & 201 & 201.4 & 142.8 \\
\hline TC & $180.6^{*}$ & 185.4 & 183.6 & 172.2 \\
\hline LDL & $103.69^{*}$ & 112.75 & 109.31 & 116 \\
\hline HDL & $41.52^{*}$ & 42.677 & 42.24 & 58.7 \\
\hline AST & $37.79^{*}$ & 75.84 & 61.38 & 23.5 \\
\hline ALP & $100.5^{*}$ & 81.71 & 88.86 & 75.37 \\
\hline FBS & $234^{*}$ & 189 & 206.1 & 122.1 \\
\hline Urea & $77.53^{*}$ & 42.23 & 55.64 & 29.8 \\
\hline Creatinine & $1.652^{*}$ & 1.028 & 1.265 & 0.85 \\
\hline TSB & $0.647^{*}$ & 0.835 & 0.764 & 0.86 \\
\hline
\end{tabular}

*Significant $(\mathrm{p} \leq 0.05)$ changes observed in all parameters in MI with angina pectoris as compared to MI general mean.

Table 5: The relationship between past history of DM and hypertension and levels of parameters in MI patients.

\begin{tabular}{|c|c|c|c|c|c|c|}
\hline $\begin{array}{l}\text { Health } \\
\text { state }\end{array}$ & $\begin{array}{l}\text { MI with } \\
\text { DM }\end{array}$ & $\begin{array}{c}\text { MI with } \\
\text { hypertens } \\
\text { ion }\end{array}$ & $\begin{array}{c}\text { MI with } \\
\text { DM and } \\
\text { hyperte } \\
\text { nsion } \\
\end{array}$ & MI only & $\begin{array}{c}\text { MI } \\
\text { Gener } \\
\text { al } \\
\text { Mean } \\
\end{array}$ & $\begin{array}{c}\text { Control } \\
\text { Mean }\end{array}$ \\
\hline No.(\%) & $9(18)$ & $9(18)$ & $15(30)$ & $17(34)$ & 50 & 10 \\
\hline TG & 277.6 & 249.6 & 179.5 & 155 & 201.4 & 142.8 \\
\hline TC & 191.3 & 193.3 & 169.8 & 186.5 & 183.6 & 172.2 \\
\hline LDL & 101.16 & 121.87 & 104.33 & 111.36 & $\begin{array}{c}109.3 \\
1\end{array}$ & 116 \\
\hline HDL & 42.222 & 40.444 & 41.133 & 44.176 & 42.24 & 58.7 \\
\hline AST & 67.22 & 66.11 & 48.47 & 67.18 & 61.38 & 23.5 \\
\hline ALP & 75.33 & 91.33 & 102.9 & 80.53 & 88.86 & 75.37 \\
\hline FBS & $302 *$ & 144.3 & $235.5^{*}$ & 162.1 & 206.1 & 122.1 \\
\hline Urea & 43.56 & 73.67 & 77.67 & 46.94 & 55.64 & 29.8 \\
\hline $\begin{array}{c}\text { Creatini } \\
\text { ne }\end{array}$ & 1.17 & 3.003 & 1.347 & 1.439 & 1.265 & 0.85 \\
\hline TSB & 0.544 & 1.27 & 0.633 & 1.242 & 0.764 & 0.86 \\
\hline
\end{tabular}

*Significant $(\mathrm{p} \leq 0.05)$ increase observed in FBS in MI with DM as compared to MI general mean.

\section{CONCLUSION}

Findings of this study concludes that:

1- TG, AST, FBS, urea and creatinine were increased in patients as compared with the controls. HDL decreased in patients as compared with the controls. No significant differences in levels of TC, LDL, ALP and TSB in patients and controls.

2- Differences in levels of TG, HDL and AST can use as a biomarker of myocardial infarction.

3- There is an increase in the incidence of MI in male, smoking cigarette and patients with DM and hypertension.

4- Significant changes observed in all parameters studied in MI with angina pectoris as compared to MI general mean.

\section{REFERENCE}

[1] K. Thygesen, JS. Alpert, HD. White, AS. \& AS. Jaffe, "Universal definition of myocardial infarction, " Circulation, 116, pp. 2634-2653, 2007.

[2] K. Thygesen, JS. Alpert, AS. Jaffe, et al., "Third universal definition of myocardial infarction," J Am Coll Cardiol, 60, pp. 1581-98, 2012.

[3] L. Jeffrey, MD. Anderson, A. David \& MD. Morrow, "Acute Myocardial Infarction, The new england journal of medicine," 376(21), pp. 20532064, 2017.

[4] U.S. National library of medicine and the National Intstitutes of Health, Medical subject headings. http://www.nlm.nih.gov/mesh/MBrowser.html. 2013.

[5] DP. Zipes, P. Libby, RO. Bonow, \& E. Braunwald, Braunwald's Heart Disease: A Textbook of Cardiovascular Medicine, W.B. Saunders Company, Philadelphia, 7th edition, 2004.

[6] MJ. Davies, "The composition of coronary-artery plaques, " N Engl J Med, 336(18), pp. 1312-4, 1997.

[7] SI. Rapaport \& LV. Rao, "The tissue factor pathway: how it has become a "prima ballerina". Thromb Haemost, 74(1), pp. 7-17, 1995.

[8] American Heart Association, Understand your risk of heart attack, 2014.

[9] JS. Alpert, K. Thygesen, E. Antman, \& JP. Bassand, "Myocardial Infarction Redefined, consensus of the Joint European society of cardiology American college of cardiology committee for the redefinition of myocardial infarction, Jam coll Cardiol, 36, pp. 959-969, 2000. 
[10] RK. Archer, LB. Jeffcott, \& H. Lehmann, "Comparative clinical haematology. Blackwell Scientific Publications, 1977.

[11] LG. Martinez, and L. Bucher, "Nursing management. Coronary artery disease and acute syndrome. Assessment and management of clinical problems," 7th ed, 784-820, 2007.

[12] F. Chang, S. Baloch, MS. Pirzado, MM. Sahito, S. Baloch, et al., "Hematological and Biochemical Variations in Myocardial Infarction," J Clin Case Rep, 5(11), pp. 648-649, 2015.

[13] S. Ahmad, M. Abdoljalal, \& Z. Farhad, "Serum lipid profiles in acute myocardial infarction patients in Gorgan," Biomedical Research, 23(1), pp. 119-124, 2012.

[14] S. Jayakrishnan, \& B. Jayanthi, "Biochemical Markers and Myocardial Infarction," Indian Journal of Research, 4(8), pp. 151-153, 2015.

[15] GF. Watts, P. Jackson, \& S. Mandalia, "Nutrient intake and progression of coronary artery disease," Am J Cardiol, 73, pp. 328-332, 1994.

[16] DS. Fredrickson, "The role of lipids in acute myocardial infarction," Circulation, 39, Suppl. IV-99-IV-III, 1969.

[17] Zampogna A, Luria MH, Mancibens SJ, Luria MA. "Relationship between lipids and occlusive coronary disease," Arch. Intern Med, 140, pp. 1067-1069, 1980.

[18] FC. Ballantyne, DA. Melville, JP. Mc Kenna, BA. Morrison, \& D. Ballantyne, "Response of plasma lipoproteins and acute phase proteins to myocardial infarction," Clin. Chim Acta, 99, pp. 85-92, 1979.

[19] MQ. Al-Ani, AM. Sameen, \& AS. Farhan, "Study of Some Physiological and Biochemical Aspects in The Serum of Myocardial Infarction Patients, Journal of Kirkuk University - Scientific Studies, "6 (2), pp. 63-72, 2011.

[20] M. Crawfored, JP. DiMarco, \& WJ. Paulus, Cardiology, 2nd ed., Mosby. Limited. Spain, 2004.

[21] G. Engstrom, P. Tyden, G. Berglund, O. Hansen, B. Hedblad, \& L. Janzon, " Incidence of myocardial infarction in women: A cohort study of risk factors and modifiers of effect," Journal of Epidemiology and Community Health, 54, pp. 104-107, 2000.
[22] DS. Prasad, Z. Kabir, AK. Dash, \& BC. Das, "Smoking and cardiovascular health: A review of the epidemiology, pathogenesis, prevention and control of tobacco," Indian Journal of Medical Science, 63, pp. 520-533, 2009.

[23] M. Boaz, Z. Matas, A. Biro et al., Serum malondialdehyde and prevalent cardiovascular disease in hemodialysis," Kidney Int, 56, pp. 1078-1083, 1999.

[24] D. Londero, \& P. Lo Greco, "Automated highperformance liquid chromatographic separation with spectrofluorometric detection of a malondialdehyde-thiobarbituric acid adduct in plasma," J Chromatography, 729, pp. 207-210, 1996.

[25] R. Avieles, A. Askari, B. Lindahl et al., "Troponin $\mathrm{T}$ levels in patients acute coronary syndromes with or without renal dysfunction," N Engl J Med, 346, pp. 2047-2052, 2002.

[26] P. Holvoet, D. Collen, \& F. Van de Werf, "Malodialdehyde-modified LDL as a marker of acute coronary syndromes, " J Am Med Assoc, 281, pp. 1718-1721, 1999.

[27] J. Thambyrajah, M. Landray, F. McGlynn, H. Jones, D. Wheeler, J. Townend, "Abnormalities of endothelial function in patients with predialysis renal failure," Heart, 83, pp. 205-209, 2000.

[28] J. Alpert, K. Thygeson, \& E. Antman, "Myocardial infarction redefined - a consensus document of the Joint European Society of Cardiology/American College of Cardiology Committee for redefinition of myocardial infarction," J Am. Coll. Cardiol. 36, pp. 959-69, 2000.

[29] PH. Baal, M. Peter \& K. Engelfriet, "Co-occurrence of diabetes, myocardial infarction, Hendriek C Boshuizen1, Jan van de stroke, and cancer: quantifying age patterns in the Dutch population using health survey data," Population Health Metrics, 9:51, 2011.

[30] J. Boras, Pavlic-Renar, N.Car, \& Z. Metelko, "Diabetes and coronary heart disease, Diabetologia Croatica,” 31, pp. 199-208, 2002.

[31] SC. Smeltzer, \& BG. Bare, Bruners \& Suddarhs textbook of medical surgical marsing, 10th ed, Philadelphia, PA:Lippincott Williams \&Wilkins, 2004. 


\section{ACKNOWLEDGMENTS}

Many thanks to the staff of laboratory in Al-Ramadi General hospital. Special thanks and gratitude are due to Dr. Mudhir Sabir Shekha, Assistant Professor of animal physiology at College of Sciences, Salahaddin University for his help and support.

\section{Biography}

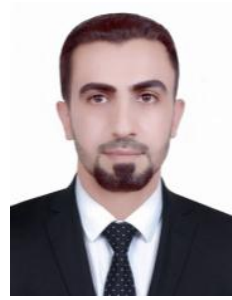

Marwan Mahmood Saleh is working now as a Assistance Lecturer in Department of Biophysics, College of Applied Sciences in university of Anbar, his BSc. (2013) and MSc. (2016) is in Biology from College of Sciences, University of Anbar, Ramadi/IRAQ,(https://scholar.google.com/citations?user $=\mathrm{iIdX0K0AAAAJ \& hl=ar}$ ) is google scholar page, and (http://orcid.org/0000-0003-2034-0128) is the ORCID link, and his Research gate link is (https://www.researchgate.net/profile/Marwan_Mahmoo d_Saleh) 